\title{
Ownership structure and loan quality of deposit money banks in Nigeria
}

\author{
Daniya Adeiza Abdulazeez
}

\author{
Department of Entrepreneurship and Business Studies, \\ Federal University of Technology Minna, Nigeria \\ email: daniyad3rd@yahoo.com
}

\begin{abstract}
Purpose - This study examined the effect of Ownership Structure (Management Shareholding and Ownership Concentration) on the loan quality (LDR) of banks in Nigeria for a period of 10 years (2008-2017). The study utilized data extracted from the annual reports of the fourteen (14) studied banks.
\end{abstract}

Method - Robustness tests were carried out to determine: the existence or otherwise of multi-collinearity, fitness of the model and appropriate regression analysis for the study. Descriptive statistics, correlation and Fixed Effect GLS regression were used to describe and analyze the data.

Result - The study found that, ownership structure (ownership concentration and management shareholding) has significant negative effect on loan quality of banks in Nigeria.

Implication - The implications of this research is that increased ownership concentration as well as management shareholding can strengthen banks' loan quality owing to reduced proportion of depositors funds used to finance loan. This could spur confidence in the bank by the general public with regards to the safety of their deposits.

Originality - This study is different from other studies that concentrated on the use of ownership structure in relations to various financial performance measurements such as ROA, ROE, NPM among other. In this study, effort was made to consider the financial health of banks owing to the nature of their business (loan).

Keywords: ownership structure; management shareholding ownership concentration; loan and deposit money bank 


\section{Introduction}

Ownership structure of every organization is a strong determinant of effective and efficient management of organizational resources especially JIAFR | 220 with the separation of ownership from the management. The study of ownership structure is very important in the banking industry owing to the tremendous roles of banks in financial intermediation. This is due to the fact that, the degree of prudence with regards to loan administration by managers of resources remains a function of the ownership patterns of such resources. Ownership structure is anintegral component of corporate governance practice which is meant to deepen effective management of resources. This is necessary to spur managerial behaviour that ensures utmost protection of interest of absentee owners as well as themanagers'themselves by ensuring strict adherence to corporate governance mechanisms such as ownership structure (Demaki, 2011). For instance Directors who subscribe to the shares of the banks they serve as directors are likely to be decorous in their lean related activities. Also, bulk shareholders have the capacity to monitor continuously the activities of the directors such that shareholders' interests are at all times protected.

This suggests therefore that, ownership structure is important to bank because they are at the fore-front of financial distress owing to the nature of the product they sell (Loans). According to Abdullatif, Freeman and Michael (2014), banks due to information asymmetry have the tendencies to adversely select high risk loan clients because they are seen to have the ability to afford the high rate of interest required by the banks. Consequently, the high loan rate may induce borrowers' investment in risky projects which further increase the possibility of loan default. It is the high rate of loan default that often leads to financial distress in several banks in Nigeria. This is evident from various financial crises such asENRON in 2001, the global financial crisis and the East Asian financial crisis which were all linked to poor and failed corporate governance practice(Alfaki, 2007; Ahmad, 2013). 
Asma'a (2014) contended that, the financial crises which started in the developed countries spread to other parts of the world, particularly Nigeria due to globalization of the financial system. The financial crisis inflicted untold financial distress on many 'too big to fall' financial institutions in Nigeria. The adverse effect of financial crisis was evident in the poor loan quality of banks being an important aspect of banks' operational activities and stability (Daniya, Tajudeen\& Mohammed, 2019). The quality of loan portfolio of banks is measured usingvarious dimensions such as ratio of non-performing loan to total loan, loan to total asset and loan to total deposit (Abdullatif, Freeman \& Michael, 2013). In order to ensure better asset quality, the ownership pattern of banks must be of serious consideration as the extent to which managers play within the rule of loan administration remains a function of their ownership stakes (Mohammed, 2012).

From the foregoing a relationship can be established between thebehaviour of managers and loan quality of deposit money banks. For instance, over the past couple of decades, banks in Nigeria were in serious financial distress which culminated into serious financial mess with its attendant poor loan quality. In a bid to sanitize that banks, Ben, Olufemi, Patrick, and James (2010) and Ezugwu and Itodo (2014) reported that, the Nigeria's apex Bank dismissed eight (8) chief executives and executive directors of some Nigerian banks between August and October, 2009 due to issues relating to poor corporate governance practice.

Sequel to the Central Bank of Nigeria (CBN) institutional arrangements aimed revitalizing the banks,different studies have been carried out to examine the effect of the arrangements either individually or collectively on various bank performance measures. However, loan quality which represents core aspect of bank operations has not enjoyed the required attention by scholars. It is on the strength of this background that, this study examined the effect of ownership structure on the loan quality of listed deposit money banks in Nigeria. 


\section{Literature Review}

\section{Ownership Structure}

JIAFR | 222

Modern corporate relationship is anchored by Agency theory which holds that there is a separation between ownership and management of firms' resources and that mangers (agents) must strive to protect the utmost interest absentee owners (shareholders). Ownership structure of banks is a deep-seated mechanism of corporate governance because of its critical role in managing agency relationship within the banking industry. According to Guiliano, Giacomo and Andrza (2006) ownership structure of banks can be viewed along two dimensions. That is, by the degree of ownership concentration and by nature of owners. This position makes no difference from the submission of Ezugwu and Itodo (2014) who also pointed out that ownership structure has to do with ownership concentration and ownership mix. Both the type and structure of bank ownership determines or explains the parties controlling the bank. To this extent, ownership structure of banks determines or explains parties controlling the bank. Ownership structure will be reviewed on the basis of ownership concentration on one hand and the nature of ownership which will cover institutional ownership and managerial ownership ( Euardus, Hermeintido\&petu, 2007).

\section{Ownership Concentration}

Ownership concentration according to Sanda, Mikailu and Garba (2005) is the 'proportion of firm's shares owned by a given number of the largest shareholders'. They further added that a high ownership concentration tends to put managers under pressure to toe the line of value maximizing behavior. In support of this submission, Alireza and Ali (2012) argued that shareholders own corporations but may not feel the sense of ownership or control over the firm because their individual stake is marginal. Shareholders' inability to monitor the activities of the management can lead to abuse and misuse of organizational resources. Consequently as the ownership stake of large block holders increases, the activities of management will be better of 
than when shareholders are dispersed (Alireza \& Ali, 2012; Nasir, Najeeb \&Saqlain 2014 and Asma'a, 2014).

John (2010) and Isenmila and Afensimi (2012) posited that large shareholders' activities can be of immense benefits to minority shareholders because they have the power and the incentive to prevent expropriation or JIAFR | 223 asset stripping by the managers. This makes ownership concentration an efficient governance mechanism. However the absence of ownership concentration makes shareholders to rely on outside directors which may lead to larger board as well as increasing agency cost (Obembe, Adebisi \& Adesina, 2011)

Also, Isenmila and Afensimi (2012) and Asma'a (2014) argued that when agency problem is controlled by block holder through close monitoring, shareholder put more reliance on the financial reports. John (2010) argued that one of the core agency problems in countries with low shareholders' protection is 'tunneling' where blockholdersconnive with the drivers of firms to expropriate minority shareholders' benefits. It was also been observed by the report of the corporate governance national technical working group (1999) that when ownership of public companies are concentrated in the hands of few individuals and family members there is tendency for unqualified family members to be appointed into managerial positions especially where there is a low level of large institutional investors representation on the board of registered firms in Nigeria.

Percentage of shareholding that constitutes threshold for ownership concentration is also of greats concern to scholars. The submissions of scholars in this regard skew towards five percent (5\%). For instance, olayinka (2010), Wei, wei, and Carol (2011), fawad (2013) and; Ezeugwu and Itodo (2014) stated that the threshold for ownership concentration is $5 \%$ and above of the total outstanding shares.

\section{Management Ownership}

The theoretical explanation of management ownership is rooted in convergence of interest hypothesis developed by Barle and Means in 1932. 
Explaining the hypothesis, Obembe et al. (2011) stated that 'given the fact that managers of organizations will pursue their selfish interest at the expense of absentee owners, an increased allocation of share to managers is expected to propel them to pursue interests that converge with those of nonmanagement shareholders'. Managers who have ownership stakes in their respective companies are poised towards taking decisions that ensure better returns to all shareholders as well as ensuring the sustainability of the company's going concern (Nasir et al., 2014).

The fact that managers own part of the company, they develop shareholders'-like interests and they are not likely to engage in behavior that is detrimental to non-management shareholders. This is said to further reduce agency conflict between the management and shareholders (Olayinka, 2010). It has also been argued that the percentage of management equity stake in the company can affect its performance. For instance, Olayinka(2010) argued that when managers acquire more shares in the company shareholders monitoring activities will decline as managers are likely to allocate more of firm's resources to themselves rather than protecting the interests of absentee owners. Isenmila and Afensimi (2012) also argued that high managerial ownership encourages aggressive earning management practice. It is clear from the above arguments that management part ownership of firms is essential to enable them put in the best effort tailored towards maximizing shareholders well being. However, when managers own substantial part of company's shares, they tend to satisfy themselves as managers than being shareholders.

\section{Loan Quality of Banks}

The quality of banks loan determines the success or failure of the banks.Mabvure, Gwangwava, Faitira, Mutibvu and Kamoyo (2012) and Kolapo, Ayeni and Oke (2012) argued that the nature of banking operations unlike manufacturing companies, expose them to default risk. This is because of the nature of product (credit) that banks sell and such loans and advances made by banks signify an important assets owned by the banks. To this end, 
banks are ordinarily meant to have high level of non-performing loans to contend with which further worsenstheir loan quality (Drehman, Soresen\&Stringa, 2008). Sonia and Monik (2014). explained that loan quality is a function of loan portfolio quality of banks which is measured by its nonperforming loan (NPL). In defining non- performing loan, Sekar and Balachandran (2014), explained that a loan is said to be non-performing, if both the interest and the principal are not paid for three months or ninety (90) days as the case may be.

Non-performing loans are highly associated with financial institutions which also represent huge determinant of the start of financial crisis in banks (Abdullatif, et al., 2014). They added that management failure to comply strictly with the code of corporate governance best practice is endemic in the Nigerian financial institutions. For example, Kolapo et al. (2012) and Abdulatif et al. (2014) documented that Nigeria banking sector has faced a number of financial challenges as a result of deteriorating loan quality occasioned by poor equity market performance, fall in global oil prices and the devaluation of currency. The poor quality of loan makes it difficult for banks to extend credit to the real sectors of the economy which consequently retard economic growth (Khalid, 2012). Ping-Fu (2014) identified different measures of banks' loan quality which include and not limited to: Non-performing loans, Loan to deposit ratio, loan to asset ratio, among others.

\section{Non-performing loans}

Banks' loan portfolio is a major measure or determinant of loan quality (Vincent \&Gumechu, 2013). Loan is one of the bank's major assets that generate substantial part of bank's income. Loan delinquency is the highest risk faced by the banks in the course of selling loans to customers (Ping-Fu 2014). A loan that is 90 days or more delinquent in both interest and principal repayment is said to be non-performing (Hifza and Aqeel, 2014). The concern of all deposit money banks is to continuously keep the rate of loan default at the lowest ebb. This will increase profitability, stability and sustainable banking practice. 


\section{Loan to Deposit Ratio (LDR)}

Another method of measuring loan quality of deposit money banks is through the loan to deposit ratio. According to Eduardus et al. (2007), the JIAFR | 226 ratio verifies the proportion of depositors' funds given out by the bank as loan/advance. When a larger proportion of banks' loans are taken out of depositors' funds, depositors' confidence on the bank to make money available on demand is threatened. They further explained that a relatively small loan to deposit ratio is a clear indication of small proportion of depositors deposit used for loan to the public. The measurement of loan to deposit ratio was given by Kolapo et al. (2012) as total loan divide by total deposit. The above positions suggested that banks' loan quality and liquidity will be threatened if significant proportion of depositors' funds is used to finance banks' loan especially in the face of heightened default rate.

\section{Loan to Total Asset Ratio}

Loan to deposit measure of loan quality of banks indicates the proportion of banks total assets that is used to finance bank loans which according to Parvash and Afroze (2014), shows bank's aggressiveness in offering loans to the members of the public. Banks tend to generate most of their income through interest when large proportion of their assets are giving out as loans and advances and it also shows the risk taken behavior of the banks (Yizhe, Claudia \& Jing-Ming, n.d). Khalid (2012) employed a different dimension in comparing loans to total assets. His argument was premised on the fact that it is not the size of banks' loan that should be compared with total asset, but the total loans in default. This according to Khalid (2012) is in line with asset quality measures using CAMEL rating. While buttressing this point, Muhammad (2011) explained that comparing non-performing loans to asset shows the extent to which banks' assets are being stressed. Banks with lower ratio of loandefault to total assets have better asset quality than banks with higher ratio of loan default to total assets (Khalid, 2012). 


\section{Conceptual Framework}

Salient concepts with regards to the subject matter have been reviewed. Evidence from extant literature revealed that ownership structure have effect of loan quality. However, researchers concentrated on the use of ownership structure and other corporate governance proxies and some performance measurements (ROA, ROE, NIM, Audit quality, Dividend policy and earnings management), while loan quality which measures the health condition of the banks has not been giving the required attention. This however, created a literature gap which this study intends to improve through its contribution. The literature gap created necessitated the development of a conceptual framework which diagrammatically shows the relationship between the dependent variable (loan quality) and independent variables (Ownership Structure) as well as the control variable (Firm age). Loan Quality in this regards was proxied using Loan to deposit ratio which ascertained the extent to which depositors' funds are used as loans to customers.

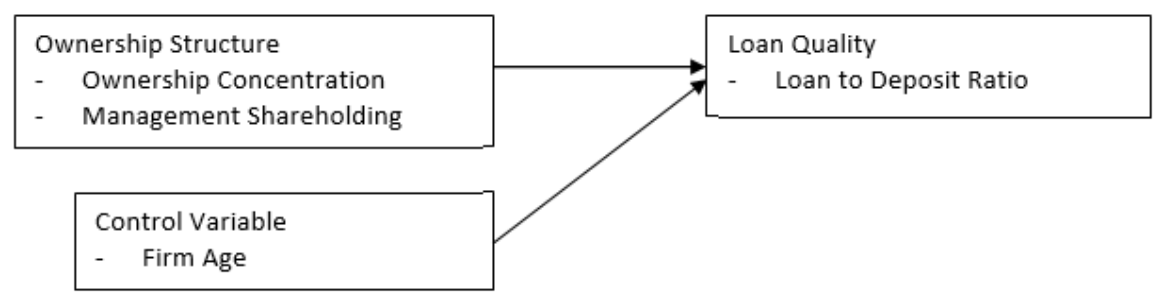

Figure 1. Conceptual Framework

\section{Hypothesis Development}

\section{Ownership Concentration and Loan Quality}

Guiliano et al. (2006) examined the effect of various alternative ownership structures, risk onthe performance of181 European banking industry drawn from 15 European countries covering a period of six (6) years (1999-2004). Data for the research were collected from the published annual financial reports of the sampled banks and were analyzed via multivariate regression analysis. The study used ownership concentration as proxy for 
ownership structure while loan quality was used as proxy for dependent variable. The study found a significant negative effect of ownership concentration on loan quality. This means that higher ownership concentration is associated with reduced non-performing loan which in turn lead to better loan quality. This finding is in compliance with the finding of Berger, Imbierowicz and Rauch (2013) on role of corporate governance in the United States bank failure during the recent crisis. Also, Shehzad, DeHaan and Scholtens (2010) found a significant negative relationship between ownership concentration and non-performing loans of five hundred (500) banks for a period of three (3) years. Also in consonance with the forgoing findings is the study of Rong, Vicky and Linda (2011) on business cycle, corporate governance, and the performance of Columbus banks with 15,000 observations spread across Georgia.

However, there is also evidence against the belief that ownership concentration leads to better loan quality of banks. For instance, Fawad (2013) examined the impact of ownership structure on non- performing loans of banks in Pakistan. The study used data from 30 out of 34 commercial banks operating in Pakistan for a period of 5years. The study employed multiple regressions to ascertain the effect of ownership concentration on non-performing loan. It was concluded that a significant position relationship exist between ownership concentration and non-performing loan. This suggests that increase in ownership concentration increased the rate of nonperforming loan and consequently worsens loan quality of banks.

Sequel to the mix findings with regards to the effect of ownership concentration on loan quality, this study therefore hypothesized that ownership concentration has no significant effect on loan quality of deposit money banks in Nigeria.

\section{Management Shareholding and Loan Quality}

Wei, et al. (2011) evaluated the impact of board ownership on the performance of Chinese banks for a period of ten (10) years spanning between 1989-2007. The study used as proxies for independent variables; 
net interest margin, ratio of non-performing loans, liquidity and loan to deposit ratio. Descriptive statistics and regression analysis were used to analyze the data collected from the financial statements of the studied banks and it was found that higher board ownership (management ownership) is negatively related to non performing loan which implies that, higher management ownership improve the loan quality of Chinese banks. This finding is in congruence with the findings of: Muhammed, Sheila, Hafiz and Ahmed (2011) on the effect of corporate governance on the asset quality of listed Malaysian banks; Berger et al. (2013) on the role of corporate governance in bank failure during the recent crisis a case study of U.S. Commercial Banks and; Rong et al. (n.d.) onthe effect of business cycle, corporate governance, and bank performance of Columbus banks. Following the findings of the study where negative relationship between management ownership and loan quality coupled with the fact that the level of such relationship was no captured in some of the reviewed studies, this study therefore hypothesized that management shareholding has no significant effect on loan quality of deposit money banks in Nigeria.

The position of scholars who found significant negative relationship between management shareholding, ownership concentration and loan quality tend to align with the argument in the literature that managers' attitude and commitment toward the effective management of the organization will be spurred when they are part owners of the organization as well as when their activities are regulated by block holders. Also the latter conclusion that found positive significant relationship cannot be undermined as evidence also revealed that ownership concentration beyond certain limit may adversely affect loan quality as blockholders strive to use their dominance to satisfy themselves at the expense of other shareholders.

\section{Theoretical Assumption}

This study is underpinned by agency theory developed by Smith (1976). The theory sees managers as agents of the principal (shareholders) whose interests must be protected at all times. Agency theory in relation to ownership structure (ownership concentration and management 
shareholding) shows that activities of banks will be properly monitored when certain individuals have major ownership stake and mangers will ordinarily engage in share holders' friendly activities when they own shares in the banks. The essence of this is to enhance the relationship between shareholders and managers. Justification for the theoretical assumption of this research relies on the fact that it allows managers to have lucid focus on individuals whose interest they serve. This will enable them to put in place appropriate measures to effectively (managerial expertise) and efficiently (cost) run the activities of the organization in a manner that the interests of their principals are put into perspective in all business dealings particularly, loan administration in banks. This will consequently reduce agency cost and agency problem in banks. Relevant studies which also used agency theory include (Segun n.d.; Sanda et al., 2005; Muhammad, 2011; Uwuigbe, 2011; Khalid, 2012; Asuagwu, 2013; Ravi \& Martin, 2013; Mansur \& Ahmad, 2013)

\section{Research Methods}

This study employs correlational ex-post facto research design using panel data for the periods under study (2008-2017). The study population consists of all the 14 banks that were listed on the Nigeria Stock Exchange as at December, 2017. A census approach was used where all the 14 banks were picked because all the banks were listed on or before 2008 and remained listed up till December, 2017.Data used in this were extracted from the published annual financial reports of the studied banks under study covering a period of 10 years (2008-2017).Variables together with the proxies used in this study are summarized in Table 1.

The study employed various statistical tools to: describe, ascertain model fitness and robustness as well analyze the data. To this extent, descriptive statistics was used to describe the nature of the variables. Also, various robustness tests (VIF, Heteroscedasticity and Hausman) were carried out to ensure that the data set were free from errors capable of invalidating the findings of this study and to ensure the fitness of the model. The relationship among the variable were ascertained via correlation while, Fixed Effect GLS 
was used in analyzing the data for the study owing to the outcome of the Breusch-Pegan test for heteroskedasticity which revealed that the data were heteroskedastic which necessitated the choice of FE-GLS via Hausman specification test.

This study adopts and modified the model used by Daniya, et al.(2019). The modified model is as follows:

$$
L D R i t=a_{0}+\beta_{1} M S_{i t}+\beta_{2} O C i t+\beta_{3} F A_{i t}+e_{i t}
$$

Where:

Where: $\mathrm{LDR}=$ Loan to Deposit Ratio, MS=Management Shareholding, OC= Ownership Concentration, FA= FirmAge, e = error term, $\mathrm{a}_{0}=$ Intercept and $\beta_{1}$ $\beta_{3}=$ Regression Coefficients

Table 1. Variables and Applicable Measurements

\begin{tabular}{ll}
\hline \multicolumn{1}{c}{ Dependent Variables } & \multicolumn{1}{c}{ Measurements } \\
\hline $\begin{array}{l}\text { Loan to deposit ratio (LDR) } \\
\text { Management Shareholding (MS) }\end{array}$ & $\begin{array}{l}\text { Total loan divided by total deposit } \\
\text { Number of shares owned by the directors } \\
\text { divide by total shares of the bank } \\
\text { Number of shares owned by individuals } \\
\text { who own } 5 \% \text { and above divide by the } \\
\text { total shares of the bank }\end{array}$ \\
Ownership concentration (OC) & $\begin{array}{l}\text { Number of years a bank was listed on the } \\
\text { Nigeria Stock Exchange }\end{array}$ \\
\hline
\end{tabular}

Source: Generated by the Authors, 2021

\section{Results and Discussion}

This section of the study analyzes and discusses the data generated quantitatively from the annual reports of the studied deposit money banks in Nigeria for a period of ten (10) years (2008-2017). This is to determine the impact of Ownership Structure (Management Shareholding and Ownership Concentration) on the loan quality of banks in Nigeria. The sequence of 
presentation of this section is in the following order:Descriptive statistics, Correlation of the variables, robustness results and regression analysis.

\section{Descriptive Statistics}

JIAFR | 232

The results of the summary statistics for the variables with regards to mean, standard deviation, minimum and maximum values are shown in Table 2.

Table 2 Shows the number of observations across the variables to be 140 which confirms that the study covers fourteen (14) listed deposit money banks for a period of ten (10) years. Ownership Concentration (OC) has a mean value of 0.2775 which means that $27.7 \%$ of the stock ownership of the studied deposit money banks is owned by investors who have $5 \%$ and above equity holdings. This ownership stake is quite high since those investors are relatively few compared to the remaining $72.3 \%$ owned by myriad of shareholders in their respective ownership stakes. Also, Ownership stake by block holders varies greatly among banks as revealed by the standard deviation value of 0.2987 .

Management equity ownership stakes in the listed deposit money banks in Nigeria has a mean value of 0.0644 which represents $6 \%$ of the total equity holding. The percentage is relatively low and varies across banks as shown by the standard deviation value of 0.112 . This low level of equity ownership by directors may inform poor corporate governance practice in banks.

The age of banks in Nigeria as measured by the number of years a bank has been listed on the floor of the Nigeria stock exchange shows mean age of 19.57 and bearing in mind the minimum age of nine (9) years and a maximum age of forty four (44) years, there is clear evidence that some banks in Nigeria are still in their infant stage and the standard deviation value of 13.4470 shows that banks vary greatly in their respective ages. 
Table 2. Showing Descriptive Statistics of the Variables

\begin{tabular}{|c|c|c|c|c|c|}
\hline Variables & OBS & Mean & Standard Deviation & Minimum & Maximum \\
\hline LDR & 140 & 0.1789775 & 0.255381 & 0.0001298 & 2.441722 \\
\hline OC & 140 & 0.2775657 & 0.2987972 & 0 & 0.959409 \\
\hline MS & 140 & 0.0644284 & 0.1122793 & 0.0001707 & 0.8769006 \\
\hline FA & 140 & 19.57143 & 13.44701 & 9 & 44 \\
\hline
\end{tabular}

JIAFR | 233

Source: Generated from the annual reports of DMBs through 'stata' 2021

\section{Correlation}

Table 3. Correlation Matrix of Dependent and Independent Variables

\begin{tabular}{lllll}
\hline & LDR & OC & MS & FA \\
\hline LDR & 1.0000 & & & \\
OC & -0.1081 & 1.0000 & & \\
MS & -0.0167 & 0.1083 & 1.0000 & \\
FA & 0.0025 & -0.2029 & -0.2829 & 1.0000 \\
\hline
\end{tabular}

Source: Generated from the annual reports of DMBs through 'stata' 2021

Table 3 presents the correlation coefficients of the Dependent Variables (LDR,), Independent Variables (Ownership Concentration and Management Shareholding) and Control Variable (Firm Age). This is necessary to establish the relationship between the explained and the explanatory variables respectively.

The results of the correlation as shown in Table 3 show the correlation coefficients of the variables which range from -1 to 1 with indicative signs (positive and negative) that denote the pattern or direction of relationship. The diagonal correlation coefficients of 1.0000 show that each variables have perfect and positive linear relationship with itself. The correlation result reveals the relationship between explanatory variables and loan to deposit ratio. The correlation result shows that ownership structure (ownership concentration and management shareholding) have negative relationship with loan to deposit ratio which suggests that, an increase in OC and MS will reduce the portion of depositors' funds used to finance loan. On the other hand, Firm Age (FA) is positively correlated with LDR, implying that an 
increase in Firm Age (FA) will also increase the proportion of depositors' funds used to finance loan which consequently worsen the loan quality of banks in Nigeria. Also, the correlation coefficients for each variable show absence of multi-collinearity as the highest correlation coefficient of 0.1083which is between Ownership Concentration and Management shareholding is less than 0.8 threshold prescribed by Gujarati (2003). The correlation result especially with regards to existence of multi-collinearity, was further confirmed through VIF test which also revealed absence of multicollineraity. Also, the results of other robustness tests show that: The Breusch-Pegan test for heteroskedasticity revealed presence of heteroskedasticity owing to the probability of the chi-square of 0.1954 which is greater than $5 \%$. Given the heteroskedastic nature of the data, the study resulted to the use of RE-GLS through the outcome of Hausman test result value of 0.043 which favoures the use of RE-GLS regression in analyzing the data.

\section{Regression Results}

Following the outcome of the hetroscedasticity and Hausman specification tests, the study resulted to the use of RE-GLS the result of which is shown in Table 4.

Table 4. RE-GLS Regression Result for the Model

\begin{tabular}{lcl}
\hline Var. & \multicolumn{1}{l}{ LDR } & LDR \\
\hline Const & 0.205 & -0.263 \\
OC & $-\mathbf{0 . 0 9 1}$ & $-\mathbf{0 . 1 2 9}$ \\
& $(\mathbf{0 . 0 1 3})^{* * *}$ & $\mathbf{( 0 . 0 1 6 ) ^ { * * * }}$ \\
MS & -0.011 & $-\mathbf{0 . 0 3 4}$ \\
& $(0.935)$ & $(\mathbf{0 . 0 3 2})^{* *}$ \\
FA & - & 0.000 \\
& & $(0.453)$ \\
$R^{2}$ & 0.31 & 0.53 \\
p-val & 0.035 & 0.044 \\
\hline
\end{tabular}

Source: Generated from the annual reports of DMBs through 'stata' 2021 
Note: The coefficients for each variable are shown in italics while their respective $p$-values in parenthesis. Variables that show significant relationship with Loan Quality are shown in asterisks together with their various degrees of significance. Three and two asterisks denote significance at $1 \%$ and $5 \%$ respectively.

The RE-GLS regression result displayed in table 4.3 shows $\mathrm{R}^{2}$ of 0.31 when the independent variables were regressed against the dependent variable without the control variable (FA) and shows also, $\mathrm{R}^{2}$ of 0.53 when control variable was included. This suggests that the predictive power of the model increases as additional variable was introduced. The extent therefore, to which the explanatory variables explained the change in the explained variable is to the tune of $53 \%$ and this is statistically significant at $5 \%$. It therefore implied that, other variables not captured in the explanatory variables account for the remaining $47 \%$.

The result shows that ownership concentration has a coefficient value of 0.091 and a p-value of 0.013 when regressed independently in relations to LDR. This revealed that OC has significant negative effect on LDR when independently examined against loan quality proxy. Also, the relationship still remained significant at $1 \%$ when regressed alongside other variables. This implies that an increase in Ownership Concentration will significantly reduce the proportion of depositors' funds used to finance loan (LDR), thereby improving the quality of loan of banks in Nigeria and vice versa. This finding is consistent with the findings of Guiliono et al. (2006), Berger et al. (2013) and Shehazed et al. (2010). Consequent upon this finding, this study rejects the null hypothesis which stated that ownership concentration has no significant effect on the lean quality of deposit money banks in Nigeria.

The random effect GLS in Table 4.3 revealed that Management shareholding has insignificant negative and insignificant impact on loan quality when regressed independently given the coefficient and p-value of 0.011 and 0.935 respectively, but became significant $(0.032)$ which is at $5 \%$ when control variable was introduced. This implies that, an increase in management shareholding will significantly reduce the proportion of depositors' funds used to finance loan by $3 \%$. The negative relationship 
between management shareholding and loan quality (LDR) is in consonace with the findings of: Wei et al. (2011), Muhammed et al. (2011) and Berger et al. (2013). Sequel to the finding, this study also rejects the null hypothesis which stated that management shareholding has no significant effect on the lean quality of deposit money banks in Nigeria.

Finally, Firm Age has insignificant impact on loan quality (LDR). This suggests that, an increase in firm age cannot be relied upon in the management of banks' loan quality. In other words, older banks have not been able to properly utilize their years of existence and experience in banking business to significantly improve their loan quality. This finding is in agreement with the finding of Wei-Kang et al. (2012).

\section{Conclusion}

The empirical relationship between Ownership Structure and Loan Quality of listed deposit money banks in Nigeria has been fully examined in this study using firm age as control variable for a study period ten (10) years (2008-2017). The result of the study revealed that the ownership stake of investors with $5 \%$ and above equity is quite high and those investors are relatively few compared to the remaining $72.3 \%$ owned by myriad of shareholders in their respective ownership stakes. Also, the ownership stake by block holders varies greatly among banks. This level of ownership state is said to have significant impact on the loan quality of the studied banks. However, the implication of increasing rate of block holdings is that it could lead to management-block-holders' connivance to expropriate the benefit accruing to other shareholders.

Similarly, Management shareholding in the listed deposit money banks in Nigeria is very low though the ownership stake by managers varies across banks. This low level of equity ownership by directors may inform poor corporate governance practice in banks. Age of banks in Nigeria as measured by the number of years of each bank since listed on the Nigerian stock exchange shows on the average shows that banks are gradually coming off the learning curve if pegged at 10 years. However, age of banks in Nigeria 
should not be seen as a reliable determinant of loan quality as some banks tend to perform poorer as they grow older and vice-versa.

Consequent upon the findings and conclusions of this study, the following recommendations have been suggested and it is anticipated that proper implementation and application of these recommendations will go a long way JIAFR | 237 in improving banks' loan quality. a) The increasing rate of Ownership Concentration should be closely monitored, as an increase beyond certain limit becomes injurious and detrimental to the well-being of other shareholders. This is premised on the fact that high ownership concentration can lead to connivance between block holders and management to expropriate the benefits due to other shareholders. b) Directors of deposit money banks in Nigeria should be compelled to subscribe to the shares of the banks to enable them develop shareholders'-like mindset in managing the affairs of the banks. c) Finally, Age of banks should be considered when assessing bank's loan quality as alder banks tend to perform poorer in terms of loan quality when growing older. Hence older banks should be monitored from time to time to ensure that they comply with corporate governance tenets that will enable them to improve their loan quality.

\section{References}

Abdul Latif, A., Anthony, K. \& Charles, A. (2013). Asset quality in a crisis period: An empirical examination of Ghanaian banks. Review of Development Finance 4, retrieved from; www.sciencedirect.com.

Abdullatif, A., Freeman, O. \& Michael, E. (2014). Does Asset quality persist on bank lending behaviour? Empirical evidence from Ghana. Global Journal of Management and Business Research Finance, 13(4) 12-22.

Ahmad, B. (2013). Corporate governance and risk exposure of banks in Nigeria, British Journal of Arts and Social Sciences, 12(1), 38-51.

Alfaki. M. (2007). Global Trend in Corporate Governance and Social Responsibility. A paper presented at the 31st conference of institute of chartered secretaries and administrators of Nigeria (ICSAN). Sheraton hotels a towers banquette hall. September 5th \& 6th, Ikeja. 
Alireza, F. (2011). The examination of the effect of ownership structure on firm Performance in listed firms of Tehran stock exchange based on the type of the industry. International Journal of Business and Management, 6(3).

JIAFR | 238 Asma'a, A. (2014). Corporate governance, ownership structure and bank performance in Jordan. International Journal of Economics and Finance, $6(6)$.

Ben, E., Olufemi, O., Patrick, S. \& James, U. (2010). Poor corporate governance and its consequences On the Nigerian banking sector. Serbian Journal of Management, 5(2).

Berger, A., Imbierowicz, B. \& Rauch, C. (2013). The role of corporate governance in bank failure during the recent financial crisis, retrieved from: www.ibierwic.com.

CBN code of corporate governance (2006).

Daniya, A. A., Tajudeen, L. \& Mohammed, Y. (2019). Board Structure and Asset Quality of Listed Deposit Money Bank In Nigeria. Jurnal Riset Akuntansi dan Keuangan, 7(1), 1-18.

Demaki, G.O. (2011). Proliferation of codes of corporate governance in Nigeria and economy development. Business Management Review, 1(6). Available @http://www.businessjournal.org/bmv.

Drehman, M., Sorensen, S. \& Stringa, M. (2008). The integrated impact of credit and interest rate risk on banks: an economic value and capital adequacy perspective, Bank of England working paper no.339.

Eduardus, T., Hermeindito, K., Putu, A. \& Supriyatna (2007). Corporate Governance, Risk Management, and Bank Performance: Does type of ownership matter?,Eadn working paper no. 34 .

Ezugwu, C. \& Itodo, A. (2014). Impact of Equity Ownership Structure on the Operating Performance of Nigerian Banks (2002-2011). Standard Global Journal of Business Management, 1(4), retrieved from; www.standardglobaljournals.com.

Fawad, A. (2013). Ownership structure and non-performing loans: Evidence from Pakistan. Asian Journal of Finance \& Accounting, 5(2), available at; www.macrothink.org/ajfa. 
Giuliano, I., Giacomo, N. \& Andrza, S. (2006), Ownership structure, risk and performance in the European banking industry, Italy, Markets and financial institutions.

Hifza, I. \& Aqeel, M. (2014). Corporate governance and its impact on performance of banking sector in Pakistan. International Journal of Academic Research in Applied Science, retrieved from; www.ijaras.isair.org.

Isenmila, P. \& Afensimi, E. (2012). Earnings management and ownership structure: evidence from Nigeria. Research Journal of Finance and Accounting, 3(7), retrieved from; www.iiste.org.

John, O. (2010). Perspectives on corporate governance challenges in a subsaharan African economy. Journal of business \& policy research, 5(1).

Khalid, A. C. (2012). The impact of asset quality on profitability of private banks in India: A case study of JK, ICICI, HDFC \& YES banks. Journal of African Economic Review, 2(1), 19-27.

Kolapo, T., Ayeni, R. \& Oke, M. (2012). Credit risk and commercial banks' performance in Nigeria: a panel model approach. Australian Journal of Business and Management Research, 2(2) 46-53.

Mabvure, T., Gwangwava, E., Faitira, M., Mutibvu, C. \&Kamoyo, M. (2012). Non-performing loans in commercial banks: A case of CBZ bank limited in Zimbabwe. Interdisciplinary Journal of Contemporary Research in Business, 4(7), retrieved from; Ijcrb.webs.com.

Mohammed, F. (2012). Impact of corporate governance on banks performance in Nigeria. Journal of Emerging Trends in Economics and Management Sciences, Jetems.scholarlinkresearch.org.

Muhammad, A., Sheila, H., Hafiz, M. \& Ahmed, K. (2011). A panel data analysis on the relationship between corporate governance and bank efficiency. Journal of Accounting Finance and Economics, 1(1) 34-41.

Nasir, A., Najeeb, M. \& Saqlain, L. (2014). The Effect of Corporate Governance on Capital Structure Decisions - A Case of Saudi Arabian Banking Sector. Oeconomica. 10(2).

Obembe, O., Adebisi, S. \& Adesina, A. (2011). Ownership Structure and Efficiency of Listed Manufacturing Firms in Nigeria. International Scientific press. 
Olayinka, M. (2010). The impact of board structure on corporate financial Performance in Nigeria. International Journal of Business and Management, 5(10).

Parvash, K. \&Afroze, N (2014). An Empirical Analysis of the Capital Adequacy in the Indian Private Banks. American Journal of Research Communication, 3(2) 14-20.

Ping-fu, L. (2014). Corporate governance and financial performance of bank in Asian regions and recommendations. Asian Journal of Finance \& Accounting, 6(2), available @www.macrothink.org/ajfa.

Ravi, P. \& Martin, H. (2013). Corporate Governance and Efficiency in Nepalese Commercial Banks. International Review of Business Research Papers 9(4) 6-11.

Rong, G.. Vicky, L. \& Linda, H. (2011). Corporate Governance and Performance in the Wake of the Financial Crisis: Evidence from us Commercial Banks. Research in Business and Economics Journal, 2(4), 23-34.

Sanda, A., Mikailu, S. \&Garba, T. (2005). Corporate Governance Mechanisms and Firm Financial Performance in Nigeria. African Economic Research Consortium, Nairobi - Kenya.

Sehrish, G., Faiza, I. \& Khalid, Z. (n.d.). Factors affecting bank Profitability in Pakistan. The Romanian Economic Journal, 1(3), 11-22.

Sekar, V. \& Balachandran, V. (2014). Asset quality of Indian banks in 20132014 - a big challenge. International Journal of Advanced Research, 4(2), 19-28.

Shehzad, C., De Haan, J. \& Scholten, B. (2010). The impact of Ownership Concentration on Impaired Loans and Capital Adequacy. Journal of Banking and Finance, 3(3), 65-69.

Vincent, O. \& Gemechu, B. (2013). Determinants of financial performance of commercial banks in kenya. International Journal of Economics and Financial Issues, 3(1), retrieved from; www.econjournals.com.

Wei, R., Wei, S. \& Carol, W. (2011). Board Governance and Performance of Chinese Banks. Banks and Bank Systems, 6(1), 22-29.

Yizhe, D., Claudia, G. \& Jing-Ming, K. (n.d) Board Governance, Efficiency and Risk Taken: The case of Chinese banking sector. 